\title{
Influence of nitrogen fertilization in mother plants on the growth and quality of clonal seedlings of Coffea canephora 'Robusta' plants
}

\author{
Alana Mara Kolln ${ }^{1,3}$ Marcelo Curitiba Espindula ${ }^{2 *}$ Larissa Fatarelli Bento de Araújo ${ }^{3}$ (D) \\ Marcela Campanharo ${ }^{4}$ (D) Rodrigo Barros Rocha ${ }^{2}$ (i) João Luiz Resende Lourenço ${ }^{5}$ (D)
}

\author{
${ }^{1}$ Instituto Federal de Educação, Ciência e Tecnologia de Rondônia (IFRO), Jaru, RO, Brasil. \\ ${ }^{2}$ Empresa Brasileira de Pesquisa Agropecuária (Embrapa Rondônia), 76815-800, Porto Velho, RO, Brasil. E-mail: marcelo.espindula@embrapa.br. \\ *Corresponding author. \\ ${ }^{3}$ Programa de Pós-graduação em Ciências Ambientais (PGCA), Fundação Universidade Federal de Rondônia (UNIR), Rolim de Moura, RO, Brasil. \\ ${ }^{4}$ Departamento de Biologia, Fundação Universidade Federal de Rondônia (UNIR), Porto Velho, RO, Brasil. \\ ${ }^{5}$ Empresa Brasileira de Pesquisa Agropecuária (Embrapa Rondônia). Ouro Preto do Oeste, RO, Brasil.
}

ABSTRACT: The nutritional management of the coffee clonal garden influences the production and physiological quality and seedlings production of vegetative propagules. Thus, this study aimed to analyze the seedlings' production from clonal cuttings taken from Coffea canephora mother plants grown with increasing nitrogen mineral doses. The cuttings were taken from C. canephora var. botany Robusta, from the Embrapa Genetic Improvement Program of Rondonia. The mother plants received nitrogen fertilizer at different doses: 0 (Control); 50; 100; 150; 200; 250 and $300 \mathrm{~kg}$ of $\mathrm{N}$ per hectare divided into 4 applications, during 150 days of orthotropic stems growth (shoots). The following parameters were evaluated: Dry mass of cuttings, nutritional content of cuttings, and seedlings production, with growth analysis at $0,48,61,80,101,122,143$, and 164 days after staking (DAS) and analysis of vegetative characteristics at 122 DAS. The nitrogen fertilization in the mother plant resulted in the variation of macronutrient accumulation in cuttings, but the order $K>N>C a>P>M g>S$ was maintained, regardless of $N$ dose. In addition, a positive correlation between nitrogen doses and dry matter accumulation, as well as the physiological quality of seedlings was identified.

Key words: clonal garden, cuttings, mineral nutrition, physiological quality.

Influência da fertilização com nitrogênio em plantas matrizes no crescimento e na qualidade de mudas clonais de plantas Coffea canephora 'Robusta'

RESUMO: O manejo nutricional do jardim clonal de cafeeiros influencia a produção e qualidade fisiológica dos propágulos vegetativos e na produção de mudas. Assim, objetivou-se analisar a produção de mudas a partir de estacas clonais retiradas de plantas matrizes de Coffea canephora cultivada com doses crescentes de nitrogênio mineral. As estacas foram retiradas de plantas matrizes de cafeeiros C. canephora var. botânica Robusta, do Programa de Melhoramento Genético da Embrapa-RO. As plantas matrizes receberam adubação nitrogenada nas doses: 0 (Controle); 50; 100; 150; 200; 250 e $300 \mathrm{~kg}$ de $\mathrm{N}$ por hectare, parceladas em quatro aplicações, durante 150 dias de crescimento das hastes ortotrópica (brotos). Os seguintes parâmetros foram avaliados: massa seca das estacas, conteúdo nutricional das estacas e a produção de mudas, com análise de crescimento, aos zero, 48, 61, 80, 101, 122, 143 e 164 dias após o estaqueamento (DAE) e a análise das características vegetativas, aos 122 DAE. A adubação nitrogenada na planta matriz resultou na variação do acúmulo de macronutrientes nas estacas, mas a ordem $K>N>C a>P>M g>S$ foi mantida independente da dose de $N$. Além disso, foi verificado que há correlação positiva entre as doses de nitrogênio e o acúmulo de massa seca, assim como, a qualidade fisiológica das mudas.

Palavras-chave: jardim clonal, estaquia, nutrição mineral, qualidade fisiológica.

\section{INTRODUCTION}

Coffea canephora is a species which reproduces by obligatory allogamy due to its characteristics of gametophytic self-incompatibility (MORAES et al., 2018). Therefore, there is high genetic variability in crops formed with seminal seedlings, resulting in plants with different production potential, (RAMALHO et al., 2016, BERGO et al., 2020), architecture (DALCOMO et al., 2017), and resistance to diseases such as coffee leaf rust (TEIXEIRA et al., 2017), which makes crop management difficult and limits crop yield (ROCHA et al., 2015).

Analternative to obtainmorehomogeneous, productive, and resistant crops is vegetative propagation. Vegetative propagation ensures that 
the genetic characteristics of the parent plant, from which the propagules are taken, are maintained and passed on to its descendants, a process called cloning (ANDRADE JUNIOR et al., 2013; RAMALHO et al., 2016). Propagation can be performed by grafting (ANDRADE JUNIOR et al., 2013), in vitro culture (SANTOS \& SILVA, 2020), or staking (VERDIN FILHO et al., 2014; VERDIN FILHO et al., 2018). Despite the different forms of propagation, staking is the main asexual reproduction technique used in seedling production in C. canephora (FERRÃO et al., 2007; VERDIN FILHO et al., 2014) due to the ease of large scale propagation (OLIVEIRA et al., 2010).

Considering that the cutting is the vegetative material that will originate the new seedling, it is important to focus on the physiological quality of this vegetative structure to obtain the highest growth rates and the greatest accumulation of dry mass of both the aerial part and the root system (GIURIATTO JÚNIOR et al., 2020). The quantity and quality of the cuttings is influenced by factors such as the time of year (BAZONI et al., 2020), as a result of variations in soil water availability, radiation, and air temperature and humidity. Factors that affect plant vegetative growth, such as the supply of water by irrigation (COVRE et al., 2016), the supply of fertilizers (DUBBERSTEIN et al., 2017), and the form of application of these fertilizers (MAGIERO et al., 2017) also result in cuttings with distinct physiological qualities.

The nutritional management of the clonal garden should take into consideration the decreasing sequence of macronutrient accumulation in the secondary orthotropic stems (shoots) (nitrogen $(\mathrm{N})>$ potassium $(\mathrm{K})>$ calcium $(\mathrm{Ca})>$ magnesium $(\mathrm{Mg})>$ sulfur $(\mathrm{S})>$ phosphorous $(\mathrm{P})$ and the export of nutrients resulting from the removal of cuttings $(\mathrm{K}>\mathrm{N}>\mathrm{Ca}>\mathrm{Mg}$ $>\mathrm{P}>\mathrm{P}>$ S) (BAZONI et al., 2020). In these vegetative structures, $\mathrm{N}, \mathrm{K}$, and $\mathrm{Ca}$ stand out as the most required nutrients, similar to the effect which occurs in fruits, in which the decreasing order of accumulation is $\mathrm{N}>$ $\mathrm{K}>\mathrm{Ca}>\mathrm{P}>\mathrm{S}>\mathrm{Mg}$ (COVRE et al., 2016).

Because $\mathrm{N}$ is the nutrient that accumulates the most in the secondary orthotropic stems from which the cuttings are taken, studying the calibration of its dosage may contribute to obtaining the maximum yield of cuttings. However, in addition to quantity, the cuttings produced also need to have physiological quality to produce well formed seedlings in the shortest possible time. Thus, the objective of this study was to analyze the production of seedlings from clonal cuttings taken from Coffea canephora mother plants grown with increasing doses of mineral $\mathrm{N}$.

\section{MATERIALS AND METHODS}

The experiment was conducted in the experimental field of EMBRAPA (longitude $10^{\circ} 43^{\prime} 55^{\prime \prime} \mathrm{S}$ and latitude $62^{\circ} 15^{\prime} 19^{\prime \prime} \mathrm{W}$, altitude of $300 \mathrm{~m}$ ), located in the municipality of Ouro Preto do Oeste, Rondônia, in the period from August 20, 2018 to July 1, 2019 and included a collection of a production of cuttings from the field and a period of production of seedlings in the nursery, where the characteristics related to growth and final quality of the seedlings were evaluated.

The predominant climate in this region is tropical monsoon - Am (Köppen) (ALVARES et al., 2013), with a mean annual temperature of $25^{\circ} \mathrm{C}$ and a mean annual rainfall of $2,000 \mathrm{~mm}$. The rainy season lasted from October-November to April-May.

The values mean of maximum, mean, and minimum temperatures and air humidity as well as rainfall for the period of growth of the cuttings (August 2018 to January 2019) and for the moment of collection (January 2019) were obtained from the automatic meteorological station installed in the experimental field (Figures $1 \mathrm{~A}, \mathrm{~B}$, and C). To replace the water lost by evapotranspiration, complementary irrigation was performed during the months of drought using a conventional sprinkler irrigation system (Figure 1C).

\section{Dry mass and macronutrient content of clonal cuttings \\ The cuttings were taken from matrix plants} of C. Canephora of the botanical variety Robusta, belonging to the Genetic Improvement Program of Embrapa-RO. The crop was established in November 2016, with the exclusive purpose of producing cuttings, in a soil classified as Red-Yellow Argisol (SANTOS et al., 2018). The spacing used was 2.0 meters between rows and 0.5 meters between plants, totaling 10,000 plants per hectare. The plants were grown with only one orthotropic stem and without bending.

In December 2017, 13 months after the establishment of the area, the first collection of shoots was performed to produce clonal cuttings. The second collection was performed in April 2018, and the third collection was performed on August 20, before the installation of the experiment. In addition to collecting the shoots, $33 \%$ of the plants' plagiotropic branches were removed at the time of harvesting and 60 days later.

The technical recommendations for fruit production were used as the basis for the nutritional management (MARCOLAN et al., 2015). The final 


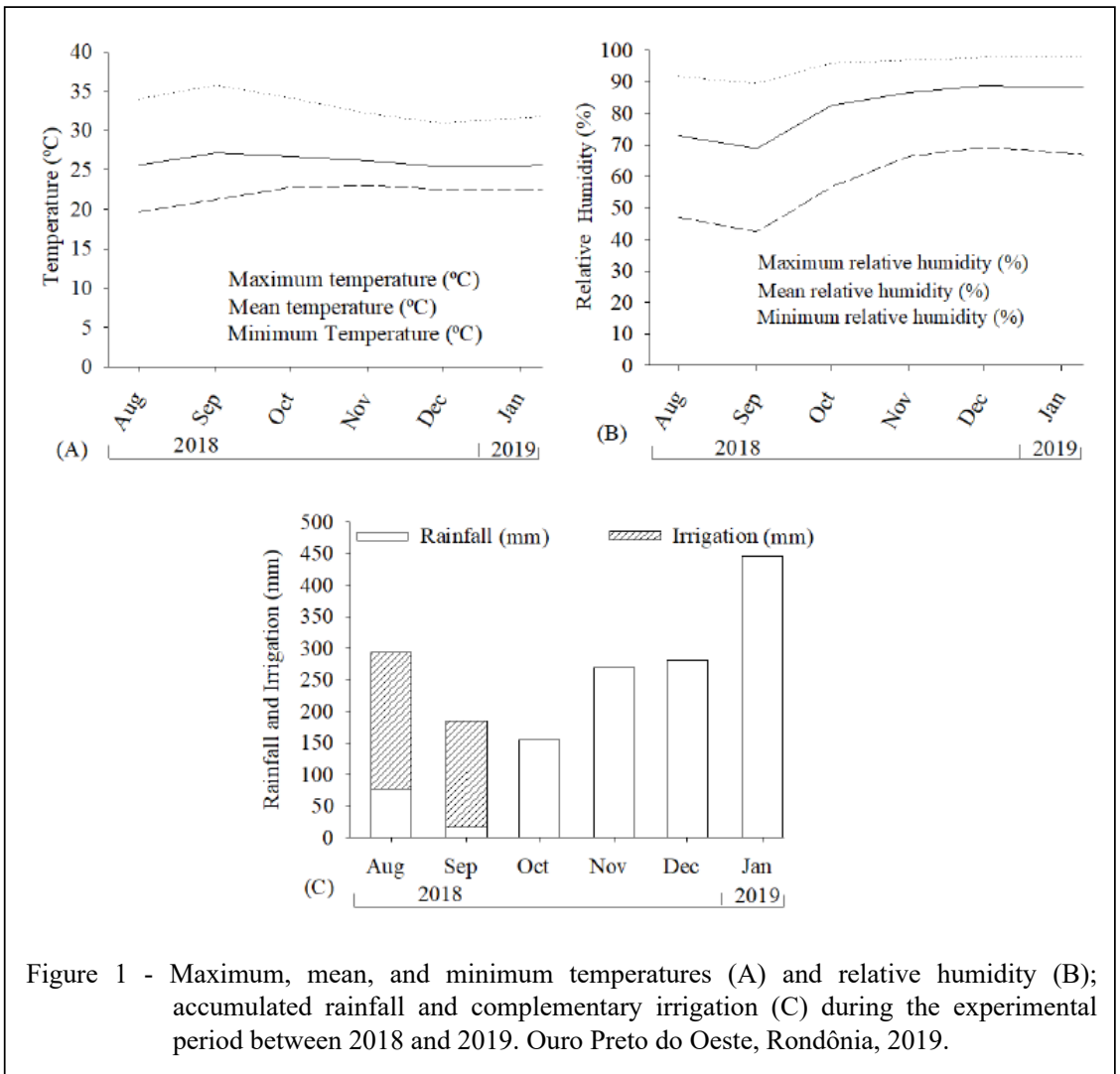

$\mathrm{N}$ fertilization of the third cycle of shoot production before the start of the treatments was performed on July 20, 2018, when $135 \mathrm{~kg}$ of $\mathrm{N}$ were applied in the form of urea. The chemical characteristics of the soil in the experimental area were determined in August 2018 , before the implementation of the treatments, in the layers 00-20, 20-40, and 40-60 cm (Table 1).

In September, $50 \mathrm{~g}$ of dolomitic limestone (PRNT 90\%) were applied, covering an area of $0.5 \mathrm{~m}$ within the row and $1.0 \mathrm{~m}$ towards the inter-rows, 0.5 to each side of the plant, totaling $0.5 \mathrm{~m}^{2}$.

The experiment included seven treatments corresponding to the following $\mathrm{N}$ doses: $0 ; 50 ; 100$; $150 ; 200 ; 250$, and $300 \mathrm{~kg}$ of $\mathrm{N}$ per hectare per cycle, applied in the form of urea, with cuttings grown from August to January 2019. The design was completely randomized, with ten repetitions.

The doses were divided into four applications, every 30 days. The beginning of the application occurred 30 days after the initial standardization, which was performed on August 20, 2018. In addition to N, $120 \mathrm{~kg}$ of $\mathrm{K}$ were applied per hectare per cycle, using potassium chloride $(60 \%$ $\mathrm{K}_{2} \mathrm{O}$ ), divided into four applications and applied together with $\mathrm{N}$. To meet the requirements for zinc and boron, $30 \mathrm{~kg}$ boric acid and $30 \mathrm{~kg}$ zinc sulfate were applied per hectare in October 2018.

The orthotropic stems (shoots) grew for 150 days and the cuttings were then collected for seedling production and nutrient content analysis. The cuttings were removed from the orthotropic stems by making rectilinear cuts $0.5 \mathrm{~cm}$ above the insertion of the plagiotropic branches and $6 \mathrm{~cm}$ below the node (leaf insertion) and discarding the basal and apical part of the stems (BAZONI et al., 2020). The plagiotropic branches were removed and the leaf limb was reduced by two thirds to prevent water loss and dehydration (DIAS et al., 2012).

To determine the dry mass of the cuttings and the nutritional content in each repetition, two cuttings were taken from the stems collected from the field with rectilinear cuts, according to the abovementioned dimensions, excluding the leaves and plagiotropic branches, which led to a total of 20 cuttings. These cuttings were homogenized to allow four repetitions containing five cuttings each. Thus, the experimental design at this stage was completely randomized with four repetitions. 
Table 1 - Chemical characteristics of an Red-Yellow Argisol soil in the clonal garden of the Experimental Field of Embrapa, Ouro Preto do Oeste, Rondônia, 2018.

\begin{tabular}{|c|c|c|c|c|c|c|c|c|}
\hline Sample & $\mathrm{pH}$ & $\mathrm{P}$ & $\mathrm{K}$ & $\mathrm{Ca}$ & $\mathrm{Mg}$ & $\mathrm{H}+\mathrm{Al}$ & $\mathrm{Al}$ & CTC \\
\hline $\mathrm{cm}$ & Water & $\mathrm{mg} \mathrm{dm}^{-3}$ & & --------- & $\mathrm{cm}$ & -3 & -----. & \\
\hline $0-20$ & 4.36 & 53.13 & 0.35 & 1.11 & 0.76 & 8.01 & 0.88 & 10.24 \\
\hline $20-40$ & 4.63 & 13.75 & 0.36 & 1.02 & 0.45 & 4.81 & 0.54 & 6.64 \\
\hline $40-60$ & 4.98 & 5.50 & 0.45 & 1.59 & 0.53 & 3.37 & 0.05 & 5.94 \\
\hline Sample & MO & $\mathrm{m}$ & V & $\mathrm{Cu}$ & $\mathrm{Fe}$ & $\mathrm{Mn}$ & \multicolumn{2}{|c|}{$\mathrm{Zn}$} \\
\hline $\mathrm{cm}$ & $\mathrm{g} \mathrm{kg}^{-1}$ & \multicolumn{2}{|c|}{--------------- \% ------------- } & ---------- & -------- & $--m g / d m$ & - & ----- \\
\hline $0-20$ & 15.20 & 31.00 & 21.13 & 42.61 & 230.16 & 119.27 & \multicolumn{2}{|c|}{49.98} \\
\hline $20-40$ & 7.70 & 25.50 & 28.00 & 19.38 & 247.83 & 120.34 & \multicolumn{2}{|c|}{46.24} \\
\hline $40-60$ & 4.95 & 2.50 & 43.00 & 15.75 & 159.01 & 119.74 & \multicolumn{2}{|c|}{40.98} \\
\hline
\end{tabular}

$\mathrm{pH}$ in water 1:2.5, O.M. by humid digestion, $\mathrm{P}$ and $\mathrm{K}$ determined by the Mehlich I method, exchangeable $\mathrm{Ca}, \mathrm{Mg}$, and $\mathrm{Al}$ extracted with $\mathrm{KCl} 1 \mathrm{~mol} \mathrm{dm}{ }^{-3}$.

The cuttings were dried in an oven with forced air circulation at $65^{\circ} \mathrm{C}$ to constant mass, and the masses were then determined using analytical scales and subsequently ground in a Willey mill and sent to the Soil and Plant Nutrition Laboratory of Embrapa Rondônia.

In the laboratory, the contents of $\mathrm{N}, \mathrm{P}, \mathrm{K}$, $\mathrm{Ca}, \mathrm{Mg}$, and $\mathrm{S}$ were determined. $\mathrm{N}$ was determined by distillation by the semi-micro Kjeldahl method, after sulfuric digestion. $\mathrm{P}$ was determined by molecular spectrophotometry; $\mathrm{K}$ was determined by flame photometry, and the nutrients $\mathrm{Ca}, \mathrm{Mg}$, and $\mathrm{S}$ were determined by plasma spectrophotometry, all after nitric-perchloric digestion (SILVA, 2009). Thus, the nutritional values and dry mass of the cuttings allowed us to calculate the nutrient content of the cuttings. The results were expressed in g/cutting).

\section{Dry mass accumulation and growth rates}

For the analysis of growth, a part of the cuttings (1,500 units) collected in the field from mother plants were sent to a nursery with $50 \%$ shade and a mist irrigation system for rooting and sprouting and subsequent seedling formation. The experiment was conducted using a $7 \times 8$ factorial scheme, composed of a combination of seven doses of $\mathrm{N}$ fertilizer applied in the field of mother plants and eight evaluation periods: zero (mass of the stake); $48 ; 61 ; 80 ; 101 ; 122 ; 143$, and 164 days after staking (DAS). The design was completely randomized with four repetitions. The experimental plot was composed of six cuttings/seedlings.

When ready for planting, the individualized cuttings were immersed in an Azoxystrobin fungicide solution (Amistar ${ }^{\circledR}$ WG) at a concentration of 25 $\mathrm{g}$ per $100 \mathrm{~L}$ of water. Each cutting was placed in a polyethylene tube with a capacity of $280 \mathrm{~cm}^{3}$. Before receiving the cuttings, the tubes were filled with Vida Verde Tropstrato HT $^{\circledR}$ commercial substrate, composed of pine bark and expanded vermiculite, simple superphosphate, and potassium nitrate. According to the manufacturer, the product had a $60 \%$ moisture and $130 \%$ water retention capacity (weight/ weight), density of $200 \mathrm{~kg} \mathrm{~m}^{-3}$ (dry base) and $500 \mathrm{~kg} \mathrm{~m}^{-3}$ (wet base), and $\mathrm{pH}$ of 5.8 and electrical conductivity of $0.5 \mathrm{mS} \mathrm{cm}^{-1}$, both at a ratio of 5:1 (water: substrate). The substrate was sumplemented with $0.5 \mathrm{~kg}$ of the fertilizer Basacot ${ }^{\circledR}$ Plus $6 \mathrm{M}(16 \% \mathrm{~N}, 8 \% \mathrm{P}, 12 \% \mathrm{~K}$, $2 \% \mathrm{Mg}, 5 \% \mathrm{~S}, 0.4 \% \mathrm{Fe}, 0.02 \% \mathrm{~B}, 0.02 \% \mathrm{Zn}, 0.05 \%$ $\mathrm{Cu}, 0.06 \% \mathrm{Mn}$, and $0.015 \% \mathrm{Mo}$ ) and $0.2 \mathrm{~kg}$ of triple superphosphate for each $100 \mathrm{~kg}$ of substrate.

The tubes with the cuttings were then placed in trays on suspended shelves inside the nursery, where they received constant irrigation through a mist irrigation system coupled to a timer programming the supply of water. The system was programmed to activate irrigation for 10 seconds every 5 minutes during the first 30 days; for 30 seconds every 20 minutes from day 30 to day 90 ; and for $60 \mathrm{~s}$ every $30 \mathrm{~min}$ from day 90 to day 120 . There was no acclimatization period as the seedlings were destroyed during the evaluations.

Seedling mass was evaluated at zero (mass of the initial stake), 48, 61, 80, 101, 122, 143, and 164 days after staking (DAS). For this purpose, the seedlings were removed from the tubes, washed to remove the substrate, and then dried in an oven with forced air circulation at $65{ }^{\circ} \mathrm{C}$ until constant mass 
was reached. Seedling mass was then determined using analytical scales. The mass results were used to construct the following curves: dry mass accumulation, absolute growth rate (AGR) $\left(\mathrm{mg} \mathrm{day}^{-1}\right)$, and relative growth rate (RGR) $\left(\mathrm{mg} \mathrm{g}^{-1} \mathrm{day}^{-1}\right)$. After evaluation at 122 DAS, fertilization was performed in each tube with $50 \mathrm{~cm}^{3}$ of calcium nitrate solution at a concentration of $5 \mathrm{~cm}^{3} \mathrm{dm}^{-3}$.

Dry mass accumulation was obtained by direct determination of the total dry mass of the plants (with the stake). AGR was calculated using the equation: $\mathrm{AGR}=(\mathrm{M} 2-\mathrm{M} 1) /(\mathrm{T} 2-\mathrm{T} 1)$, where M2M1 is the change in the mass of dry matter between two consecutive samples taken at times $\mathrm{T} 1$ and $\mathrm{T} 2$ and RGR was calculated using the equation: $R G R=(\operatorname{lnM} 2$ - lnM1) / (T2 -T1), where ln is the Neperian logarithm and $\mathrm{M} 1$ and $\mathrm{M} 2$ represent the dry masses at times $\mathrm{T} 1$ and T2, respectively (PEIXOTO et al., 2011).

Vegetative characteristics of the seedlings 122 days after staking

At 122 days after staking (DAS), concomitantly with the evaluation of dry mass accumulation and growth rates, the seedlings were assessed for their vegetative characteristics. This period was chosen as it is the average time for the formation of clonal seedlings of $C$. canephora in the state of Rondônia (ESPINDULA et al., 2015). The following parameters were evaluated: 1) stem length (SL), by direct measurement from the insertion point of the shoot at the stake to the apical meristem; 2) stem diameter (SD), determined at the base of the branch, $3 \mathrm{~cm}$ above the insertion point of the shoot at the stake; 3 ) number of roots (NR) by direct counting; 4) root volume (RV), determined using a graduated cylinder and recording the displaced volume; 5 ) dry mass of the aerial part (DMAP), determined using the cuttings and the shoot, 6) dry mass of the roots (DMR), determined using analytical scales after drying in an oven with forced air circulation at $105{ }^{\circ} \mathrm{C}$ to constant mass; 7) total dry mass (TDM), determined by the sum of DMAP and DMR, 8) leaf area (LA), determined using the Determinador Digital de Área (DDA) software (FERREIRA et al., 2008); and 9) Dickson quality index (DQI), obtained from the formula DQI $=[\mathrm{TDM} /[(\mathrm{SL} / \mathrm{SD})+(\mathrm{DMAP} / \mathrm{DMR})]$ (DICKSON et al., 1960).

\section{Statistical analysis}

The data were submitted to regression analysis. The mathematical models were chosen by considering the criterion of maximum parsimony (FERREIRA, 2018), which considers two characteristics for selection: higher estimates of the coefficients of determination $\left(\mathrm{R}^{2}\right)$ and greater simplicity of the model, according to the behavior of the biological phenomenon. The significance of the regression coefficients ( $\beta \mathrm{i}$ ) was evaluated using analysis of variance at $5 \%$ probability. Even for the characteristics that did not have significant treatment effects, scatter plots of the means with confidence intervals were presented. In this case $\hat{Y}$ mean.

$$
\begin{aligned}
& \hat{Y}=\beta_{0}+\beta_{1} x \\
& \hat{Y}=\beta_{0}+\beta_{1} x+\beta_{2} x^{2} \\
& \hat{Y}=\beta_{0}+\beta_{1}^{x}
\end{aligned}
$$

$\hat{Y}=$ response variable (mass production and nutrient content), $\mathrm{x}$ : explanatory variable (doses of $\mathrm{N}), \beta_{0}, \beta_{1}$, $\beta_{2}=$ regression parameters quantifying the changes in the response variable due to changes in the explanatory variable.

\section{RESULTS}

Dry mass and macronutrient content of clonal cuttings

The increase of the $\mathrm{N}$ dose promoted an exponential decrease in the dry mass of the cuttings, from $1.31 \mathrm{~g}$ per cutting at the smallest doses to 1.05 $\mathrm{g}$ per cutting in the propagules that grew under the highest doses (Figure 2).

The $\mathrm{N}, \mathrm{K}$, and $\mathrm{Ca}$ contents of the $C$. Canephora cuttings were affected by the amount of $\mathrm{N}$ (Figure 3). N showed a linear increasing behavior, $\mathrm{K}$ had a quadratic behavior with a maximum point at 258 $\mathrm{kg} \mathrm{ha}^{-1}$ of $\mathrm{N}$, and $\mathrm{Ca}$ had a linear decreasing behavior. The other nutrients, $\mathrm{P}, \mathrm{Mg}$ and $\mathrm{S}$, were not influenced by increasing $\mathrm{N}$ doses.

\section{Dry mass accumulation and growth rates}

Regardless of the $\mathrm{N}$ dose, dry mass accumulation (DMA) increased exponentially over the period of seedling formation. The seedlings produced using cuttings from the treatments with the highest doses of $\mathrm{N}$ exhibited the lowest initial mass; the mass of the $300 \mathrm{~kg}$ treatment of $\mathrm{N}$ per hectare was initially $1.07 \mathrm{~g}$ seedling ${ }^{-1}$ and, with increasing DAS, the DMA of these seedlings was the highest $\left(4.32 \mathrm{~g} \mathrm{seedling}^{-1}\right)$. The opposite phenomenon was observed for the seedlings under the control dose of $\mathrm{N}$, which initially exhibited the highest dry mass $\left(1.20 \mathrm{~g}\right.$ seedling $\left.{ }^{-1}\right)$ and had the lowest DMA at the end of the cycle (3.21 $\mathrm{g}$ seedling $^{-1}$ ) (Figure 4).

With regard to the relative and absolute growth rates, as there was no interaction between the evaluation periods and the doses of $\mathrm{N}$, the mean results of the behavior of these characteristics over time are presented (Figure 5). The mean relative and absolute growth rates were characterized by a slow 


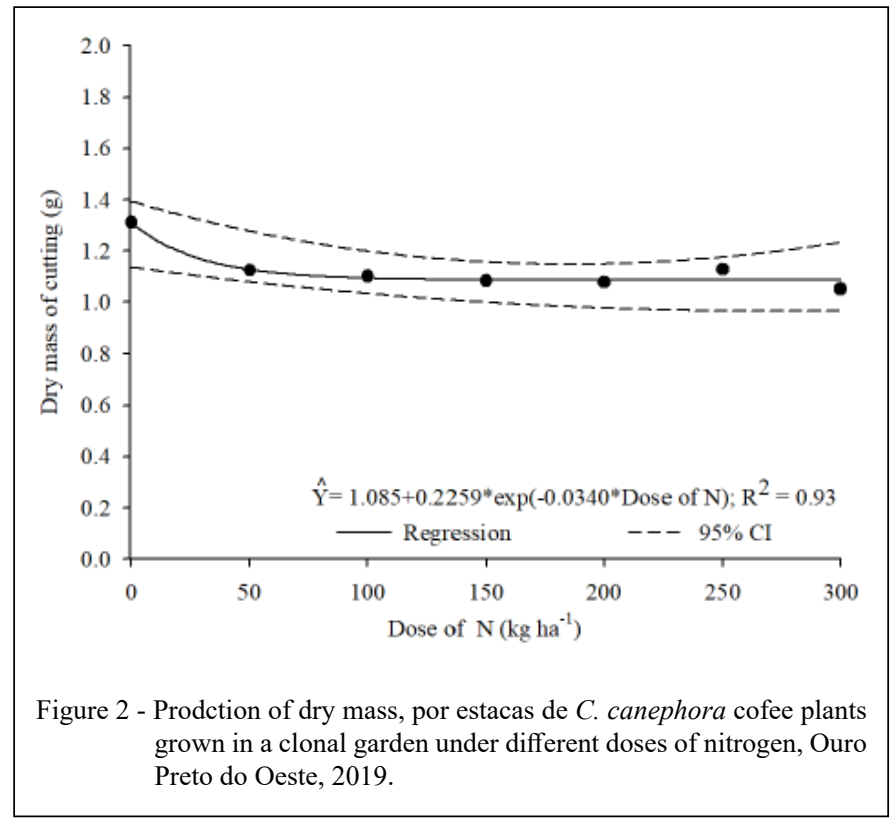

initial increase (until day 48), which was followed by rapid increase until day 61 , and thereadter, the increase in mass occurred in a linear manner until 122 DAS. From 122 DAS (when calcium nitrate was applied) until 143 DAS, there was a phase of accentuated growth. After 143 DAS, the seedlings' growth rates slowed down again. The growth rates did not fit any mathematical model, but two growth peaks were observed at 61 and 143 DAS, with AGR of $16.42 \mathrm{mg} \mathrm{day}^{-1}$ and $35.39 \mathrm{mg}$ day $^{-1}$ and RGR of $11.09 \mathrm{mg} \mathrm{mg}^{-1}$ day $^{-1}$ and $12.11 \mathrm{mg}$ $\mathrm{mg}^{-1}$ day $^{-1}$, respectively (Figure 5).

Vegetative characteristics of seedlings at 122 days after staking

There was a linear increase in the vegetative characteristics SL, SD, NR, RV, LA, DMAP, and TDM of the seedlings from the lowest dose of $\mathrm{N}$ applied to the mother plants. NR showed a quadratic behavior, with maximum points obtained at $81 \mathrm{~kg} \mathrm{ha}^{-1}$ of $\mathrm{N}$, whereas DMR and DQI were not influenced by the doses of $\mathrm{N}$ applied to the mother plants. The mean values of DMR and DQI were 0.46 $\mathrm{g}$ and $0.34 \mathrm{~g}$ respectively (Figure 6).

\section{DISCUSSION}

Dry mass and macronutrient content of the clonal cuttings

An increase in $\mathrm{N}$ resulted in a a reduction in the dry mass of the cuttings. This occurred because increasing $\mathrm{N}$ promotes vegetative growth and stem elongation (CIRIELLO, GUERRINI \& BACKES, 2014; SOARES et al., 2017), i.e., the greater availability of $\mathrm{N}$ may have resulted in thinner or less dense stems that were therefore lighter due to the competition for resources, such as solar radiation, caused by the higher number of secondary stems and cuttings and greater fresh mass of the stems (data not shown).

The increase in $\mathrm{N}$ content as a function of the $\mathrm{N}$ dose occurred due to the greater availability of $\mathrm{N}$ in the soil for absorption by the roots. With regard to $\mathrm{K}$, no increase in the content of this nutrient was expected in the cuttings because the source of $\mathrm{N}$, urea, did not have $\mathrm{K}$ in its composition. This source is rapidly hydrolyzed in the soil, releasing ammonium $\left(\mathrm{NH}^{4+}\right)$, which could have a negative effect on the uptake of $\mathrm{K}+$ (HOLZSCHUH et al., 2011).

However, the fertilizer was divided into four applications throughout the cycle. Moreover, there was a period of approximately 30 days between the last application of fertilizer and the collection of the cuttings. As the soil was highly acidic, water was available, and the temperature was high, it can be assumed that there was transformation of $\mathrm{NH}^{4+}$ into nitric forms $\left(\mathrm{NO}^{2-}\right.$ and $\left.\mathrm{NO}^{3-}\right)$ through the nitrification process, and that this favored the uptake of $\mathrm{N}$ in the nitric form. When anion uptake occurs, an increase in the uptake of cations tends to occur to maintain the ionic balance in the tissues (BATISTA \& MONTEIRO, 2010; ROCHA et al., 2014). It is of note that this nutrient 


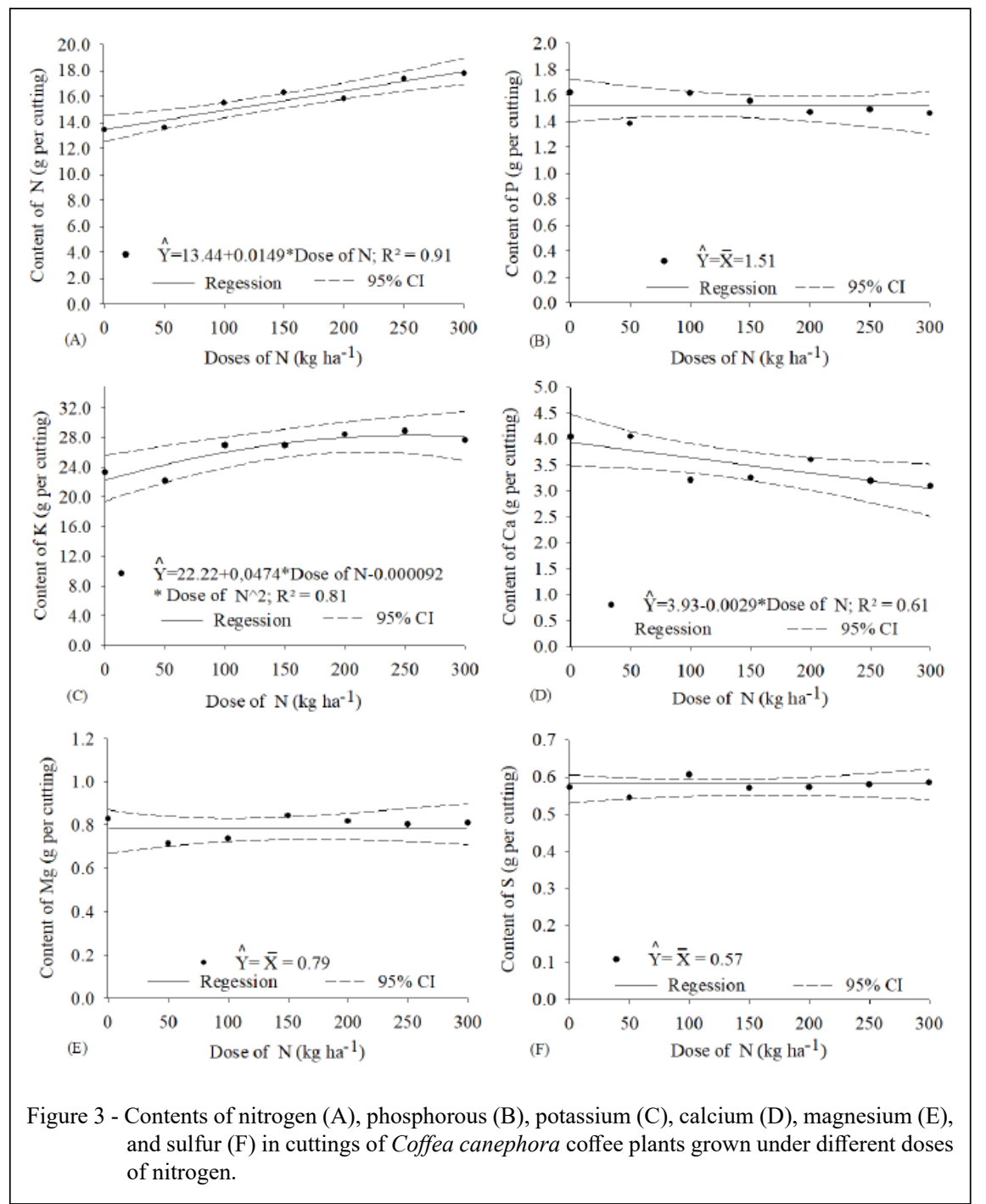

was already present in the soil at a concentration of 0.35 to $0.45 \mathrm{cmolc} \mathrm{dm}^{-3}$ (Table 1), and $150 \mathrm{~kg}$ of $\mathrm{K}_{2} \mathrm{O}$ per hectare were further added during the growth cycle of the stems.

The decrease in the Ca content (Figure 3D) of the cuttings may be associated with the effect of competition between cations, because there was an increase in the $\mathrm{K}$ content of the tissues. This occured because $\mathrm{K}$ is absorbed preferentially to $\mathrm{Ca}$, as it is a monovalent cation and has a smaller ionic radius (MONTES et al., 2016). It should also be emphasized that there was low availability of $\mathrm{Ca}$ in the soil and the applied lime may not have provided $\mathrm{Ca}$ in time for the uptake by the parent plants.

Another relevant observation was the fact that the content of $\mathrm{K}$ was higher than that of $\mathrm{N}$ in the cuttings (Figures $3 \mathrm{~A}$ and $\mathrm{C}$ ). This result is possibly related to the role of $\mathrm{K}$ in the functions of maintenance of the osmotic balance of plants (OOSTERHUIS et al., 2014). This higher $\mathrm{K}$ content may be of special importance during the rooting phase of cuttings in the nursery, because it acts in the maintenance of cell turgor. This physiological condition is important in cuttings at the beginning of the rhizogenesis process (CUNHA et al., 2009).

The sequence of macronutrient accumulation in the cuttings was $\mathrm{K}>\mathrm{N}>\mathrm{Ca}>\mathrm{P}$ $>\mathrm{Mg}>\mathrm{S}$, unlike that reported for conilon coffee plants $(\mathrm{K}>\mathrm{N}>\mathrm{Ca}>\mathrm{Mg}>\mathrm{P}>\mathrm{S}$ ) (BAZONI et al.., 2020) in which the cuttings exported more $\mathrm{Mg}$ than $\mathrm{P}$. However, the cuttings evaluated in the study had two thirds of the leaves, exactly as they are used for the 


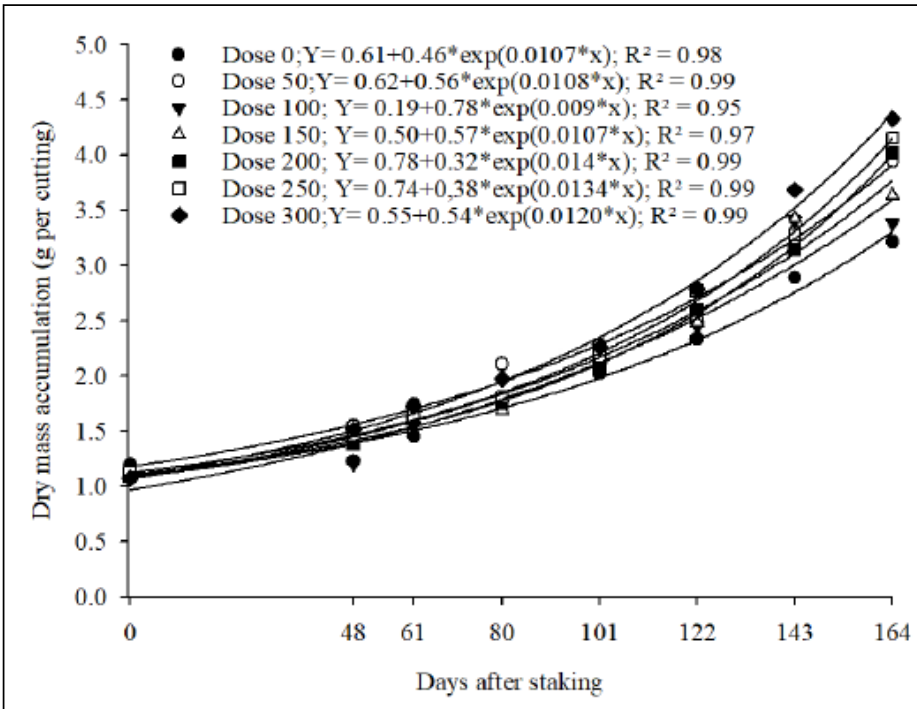

Figure 4 - Dry mass accumulation in seedlings of Coffea canephora coffee plants formed from cuttings grown under different doses of nitrogen.

production of seedlings, whereas in the present study, only cuttings without leaves were analyzed.

These results reinforce the importance of $\mathrm{N}$, $\mathrm{K}$, and $\mathrm{Ca}$ in clonal garden nutrition, but it is important to note that the other macronutrients $(\mathrm{P}, \mathrm{Mg}$, and $\mathrm{S})$ should not be neglected; they are important for plant development because they participate in the processes of respiration ( $\mathrm{P}, \mathrm{Mg}$ and $\mathrm{S})$, carbohydrate metabolism ( $\mathrm{P}$ and $\mathrm{S}$ ), protein synthesis ( $\mathrm{Mg}$ and $\mathrm{S}$ ), and nucleic acid synthesis (P and Mg) (CUNHA et al., 2009).

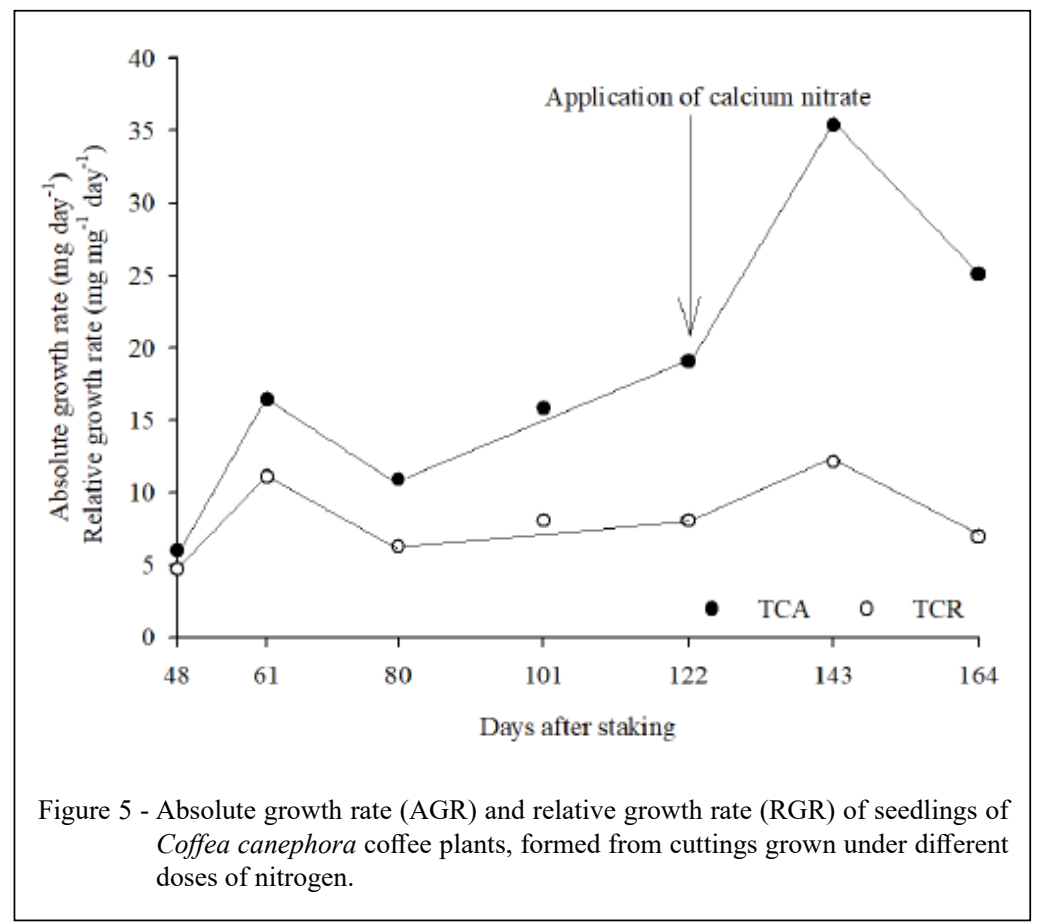

Ciência Rural, v.52, n.9, 2022. 
Dry mass accumulation and growth rates

The slow growth observed in the initial phase (48 DAS) is related to the absence of absorbing roots. During this period, the cuttings depend on their nutrient reserves to survive and promote the process of root initiation (CUNHA et al., 2009, DIAS et al., 2012). Therefore, this is considered one of the most critical phases for the survival of cuttings in the propagation method, because the absence of roots limits the withdrawal of water and nutrients from the substrate (PETRY et al., 2012). Thus, as the root system develops, there is an accumulation of mass up to $164 \mathrm{DAS}$.

In the evaluation on the $164^{\text {th }} \mathrm{DAS}$, the cuttings produced with the dose of $300 \mathrm{~kg}$ of $\mathrm{N}$ originated seedlings with $4.32 \mathrm{~g}$ of dry matter, while the seedlings originating from cuttings produced with the control dose (zero) resulted in seedlings

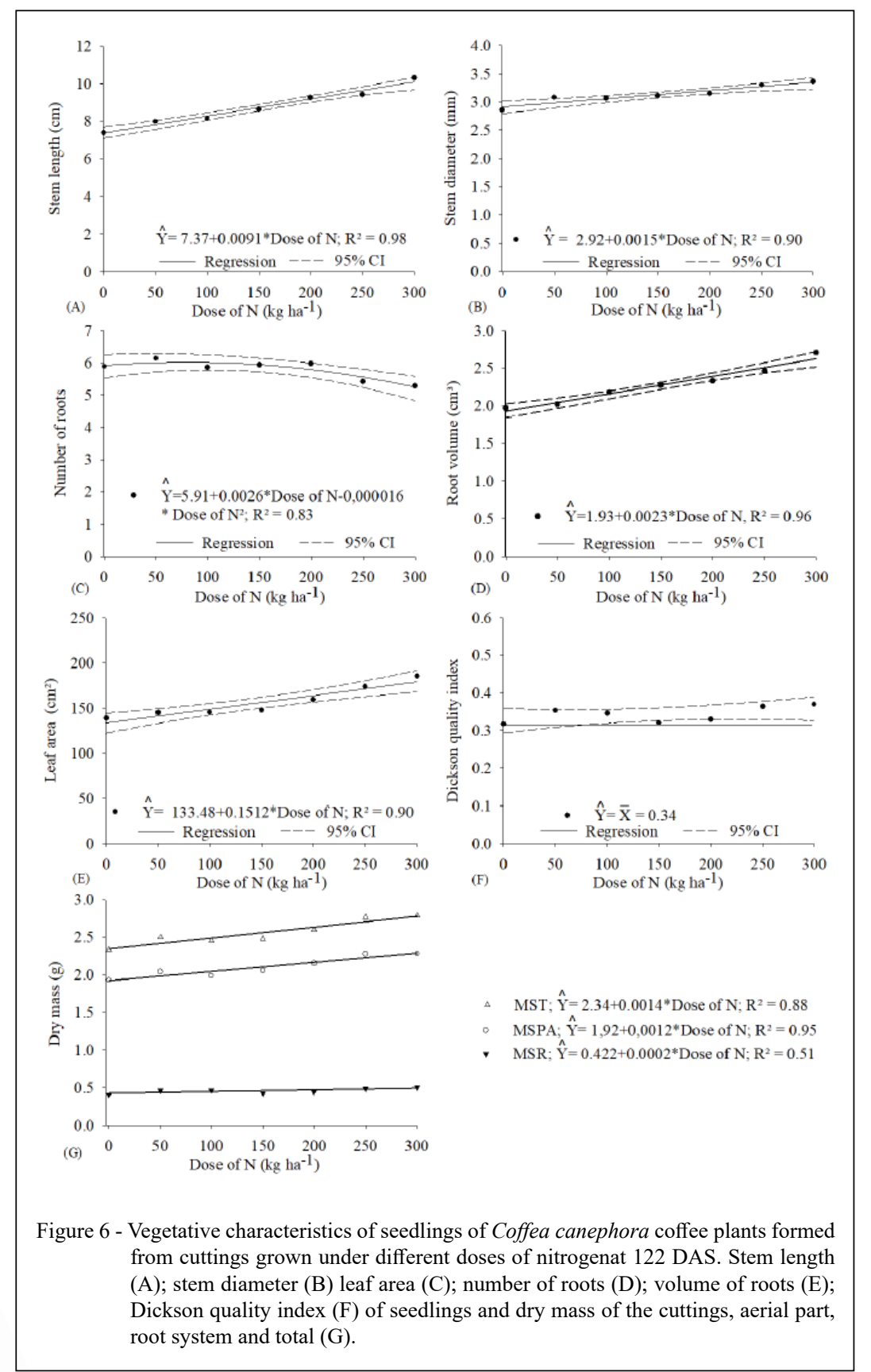

Ciência Rural, v.52, n.9, 2022. 
with $3.21 \mathrm{~g}$ of dry mass. This greater mass of the seedlings from cuttings grown under the higher doses of $\mathrm{N}$ is related to the beneficial effects of this nutrient on the vegetative propagule regarding rooting and development of the aerial part (COLODETTI et al., 2015; PICOLOTTO et al., 2015).

Regardless of the doses of $\mathrm{N}$, the final values of dry mass were below those reported for C. canephora seedlings produced with cuttings of different ages, which were above $4.8 \mathrm{~g}$ per seedling at $168 \mathrm{DAS}$, regardless of the age of the cuttings (GIURIATTO JÚNIOR et al., 2020). The differences indicate that aspects related to the management of the seedlings in the nursery may have influenced their development, because the genetic material used in this study was the same as that used by those authors. Moreover, no stabilization was observed in the rate of mass accumulation at the end of the cycle, which usually occurs due to the limited volume of the container (ESPINDULA et al., 2018; GIURIATTO JÚNIOR et al., 2020), when the root system is well developed.

The AGR and RGR curves were similar, with two growth peaks. The first peak occurred betwen the $48^{\text {th }}$ and the $61^{\text {st }}$ DAS and the second between the $122^{\text {nd }}$ and the $143^{\text {rd }}$ DAS (Figure 5). In the first case, the high growth rates are related to the emergence of roots and consequent absorption of water and nutrients from the substrate, which indicates that there was early root emission; in this context, Giuriatto Junior et al. (2020) reported elevation of AGR and RGR only after the $83^{\text {rd }}$ DAS. However, unlike what was reported by these authors, there was a decrease in growth rates from the $61^{\text {st }}$ to the $80^{\text {th }} \mathrm{DAS}$, with resumption in the following evaluations. This unexpected reduction may be related to adjustments in the irrigation system for water supply, a factor that can be decisive in the seedling development process (BAZONI, 2018).

The second growth peak resulted from the application of calcium nitrate $\left(\mathrm{Ca}\left(\mathrm{NO}_{3}\right)_{2}\right)$. This fertilizer is composed of $14 \% \mathrm{~N}$ and $28 \% \mathrm{Ca}$, two of the nutrients most accumulated in the cuttings, together with $\mathrm{K}$. In addition to the effect of $\mathrm{N}, \mathrm{Ca}$ probably contributed significantly to the second peak. This is because the contents in the cuttings were low (up to $4 \mathrm{mg}$ per cutting) compared to the contents found in Conilon coffee plants (10.7 $\mathrm{mg}$ per cutting) (BAZONI, 2018) and Robusta coffee plants (9 mg per cutting) (GIURIATTO JÚNIOR, 2020).

In addition to the low content of $\mathrm{Ca}$ in the cuttings, this nutrient has low mobility in the tissues (TAIZ et al., 2017), and the Basacote ${ }^{\circledR}$ fertilizer used in the preparation of the substrate does not contain
Ca. This nutrient can limit the growth of seedlings of woody species (GONÇALVES et al., 2013), because it participates in the process of auxin hormone metabolism, cell division, peroxidase metabolism, and cell elongation (CUNHA et al., 2009). In response to an increase in the $\mathrm{Ca}$ content of the substrate, seedling development was improved by the increase in the production of dry matter (GONÇALVES et al., 2013), as well as seedling height and diameter (ESTEVEZ et al., 2020). In addition, Ca has a structural function in the formation of the cell wall and constitutes the middle lamella, which gives the plant rigidity (TAIZ et al., 2017).

Calcium nitrate was applied only after 122 DAS to avoid an effect of the fertilizer on seedling formation, which ended at this moment of evaluation. This is because the main objective of this study was to evaluate the effect of the quality of the cuttings on seedling formation, which lasts approximately 120 days. The aim of staking the seedlings for another 42 days was to assess their growth behavior after the commonly used period, because the growth of seedlings in tubes can be limited by the volume of the container (Espindula et al., 2018), which was not observed until the $164^{\text {th }}$ DAS. This may have occurred due to the availability of $\mathrm{Ca}$, and/or other factors related to seedling management in the nursery limited the growth of seedlings in the initial phase, from day zero to 122 DAS.

\section{Vegetative characteristics of seedlings at 122 days after staking}

The linear increase in the values of the vegetative characteristics at 122 DAS as a function of $\mathrm{N}$ doses (Figure $3 \mathrm{D}$ ) is related to the greater availability of the nutrient for the synthesis of nitrogen compounds, such as proteins and chlorophyll, and to the lower degree of lignification of the cuttings, considering that this occurs due to the increased growth of the stems, reduction of dry mass, and the lower concentrations of $\mathrm{Ca}$ in younger tissues (TAIZ et al., 2017).

With regard to the synthesis of compounds, the $\mathrm{N}$ present in the cuttings contributed to the development of the seedlings, because it is an essential nutrient in physiological processes such as photosynthesis, respiration, and cell differentiation (TAIZ et al., 2017). Thus, it correlates positively with seedling production, because of the storage of reserves in the cuttings and with the development of the aerial part (COLODETTI et al., 2015), e.g., stem length (PICOLOTTO et al., 2015), and with biomass increment (GONÇALVES et al., 2013). 
The greater leaf area provided by $\mathrm{N}$ fertilization in the parent plants allows a greater surface area for light interception and, consequently, higher photosynthetic rates due to the greater capacity for carbon assimilation (PARTELLI et al., 2006). This favors plant development by leading to greater accumulation of dry matter (CRUZ et al., 2007). However, one cannot fail to take into consideration that the adequate proportionality between the systems of the aboveground part and the root is directly related to the potential loss of water through transpiration due to absorption by the root (GROSSNICKLE, 2012).

With regard to the number of roots, the positive effects of $\mathrm{N}$ fertilization on root development were observed until a maximum point was reached at $81 \mathrm{~kg} \mathrm{ha}^{-1}$. From this point onwards, root development declined, possibly due to the content of $\mathrm{N}$ in the cuttings being higher than that of carbohydrates. This may have led to a lower $\mathrm{C} / \mathrm{N}$ ratio that disfavors adventitious rooting, because carbohydrates are energy sources for the initiation of root primordia (CUNHA et al., 2009; HARTMANN et al., 2011).

These results not only show the importance of $\mathrm{N}$, but also confirm the fact that the physiological condition of the parent plant influences the rooting of the cuttings (PICOLOTTO et al., 2015). This is because mineral nutrition generates a response in the formation, quantity, length and density of adventitious roots (CUNHA et al., 2009).

This response to $\mathrm{N}$ fertilization of the mother plants was observed in the formation of a greater volume of roots in the seedlings. Volume, number, and mass of dry matter of the roots characterize the efficiency of the root system (ALBERTINO et al., 2012). Seedlings with a larger root system size have a greater capacity to prevent drought and stress, as well as to improve the survival response after planting in the field (GROSSNICKLE, 2012).

The Dickson quality index (DQI) is a parameter used as a reference to verify the quality of seedlings. Although this parameter was not influenced by the doses of $\mathrm{N}$ (Figure $6 \mathrm{~F}$ ), the biometric characteristics chosen to compose the evaluation of the index showed positive differences due to increasing doses (Figure 6 A, B, G). Taken together, these results confirm the importance of the nutritional condition of parent plants for the physiological quality of seedlings reported in other studies (CUNHA et al., 2009; DIAS et al., 2012; OLIVEIRA et al., 2019). In this study specifically, the results of fertilization of the parent plants with $\mathrm{N}$ reinforce the idea that adequate fertilization of the donor plant with $\mathrm{N}$ influences the physiological caracteristcs of seedlings.

\section{CONCLUSION}

The content of nutrients in the cuttings followed the decreasing order $\mathrm{K}>\mathrm{N}>\mathrm{Ca}>\mathrm{P}>\mathrm{Mg}$ $>\mathrm{S}$, independently of the dose of $\mathrm{N}$ applied to the parent plant. Increasing doses of $\mathrm{N}$, provided in the form of urea, during the cultivation of mother plants of C. Canephora increased the content of $\mathrm{N}$ and $\mathrm{K}$ in the cuttings, while decreasing the content of $\mathrm{Ca}$, but di not alter the contents of $\mathrm{P}, \mathrm{Mg}$, and $\mathrm{S}$.

Cuttings grown with higher doses of $\mathrm{N}$ originate seedlings with greater $\mathrm{SL}$ and $\mathrm{SD}, \mathrm{RV}, \mathrm{LA}$, TDM, and DMAP.

\section{ACKNOWLEDGEMENTS}

The authors would like to thank the Instituto Federal de Educação, Ciência e Tecnologia de Rondônia for the financial contribution destined to the publication of the article, to the Consórcio Brasileiro de Pesquisa e Desenvolvimento do Café (Consórcio Pesquisa Café) for the financial support, to the Coordenação de Aperfeiçoamento de Pessoal de Nível Superior (CAPES), for the financial support and to the by PNPD grant awarded to LFBA (Brasil - Finance code 001), and the Conselho Nacional de Desenvolvimento Científico e Tecnológico (CNPq) for the "productivity in research" grant awarded to MCE and RBR.

\section{DECLARATION OF CONFLICT OF INTEREST}

The authors declare no conflict of interest. The funding institutions played no role in the study design, in data collection, analysis, or interpretation, in the writing of the manuscript, or in the decision to publish the results.

\section{AUTHORS' CONTRIBUTIONS}

All authors contributed equally to the conception and writing of the manuscript. All authors critically reviewed the manuscript and approved the final version.

\section{REFERENCES}

ALBERTINO, S. M. F., et al. Rooting of guaranazeiro cultivars cuttings with fertilization of mother plants. Pesquisa Agropecuária Brasileira, v.47, n.10, p.1449-1454, 2012. Available from: $<$ https:// doi.org/10.1590/S0100-204X2012001000006>. Accessed: Apr. 02, 2021. doi: 10.1590/S0100-204X2012001000006.

ALVARES, C. A., et al. Koppen's climate classification map for Brazil. Meteorologische Zeitschrift, v.22, p.711-728, 2013. Available from: <https://doi.org/10.1127/0941-2948/2013/0507>. Accessed: Oct. 22, 2020. doi: 10.1127/0941-2948/2013/0507.

ANDRADE JÚNIOR, S., et al. Comparison between grafting and cutting as vegetative propagation methods for conilon coffee plants. Acta Scientarium. Agronomy, v.35, n.4, p. 461-469, 2013. Available from: <https://doi.org/10.4025/actasciagron. v35i4.16917>.Accessed: Oct. 22, 2020. doi: 10.4025/actasciagron. v35i4.16917. 
BATISTA, K. et al. Variations in potassium, calcium and magnesium contents in marandu grass fertilized with nitrogen and sulfur doses. Revista Brasileira de Ciência do Solo, v.34, n.1, p.151-161, 2010. Available from: <https://doi.org/10.1590/S010006832010000100016>. Accessed: Oct. 22, 2020. doi: 10.1590 S0100-06832010000100016.

BAZONI, P. A. Quality of cuttings for production of clonal seedlings of Coffea canephora at different times of the year. 2018. 56f. Dissertation (Academic Master in Environmental Sciences) - Postgraduate Course in Environmental Sciences, Federal University of Rondônia Foundation, Rolim de Moura, RO.

BAZONI, P. A., et al. Production of cuttings and nutrient export by Coffea canephora in different periods in the Southwestern Amazon. Revista Brasileira de Engenharia Agrícola e Ambiental, v.24, n.3, p.162-169, 2020. Available from: <https:// doi.org/10.1590/1807-1929/agriambi.v24n3p162-169>. Accessed: Oct. 22, 2020. doi: 10.1590/1807-1929/agriambi.v24n3p162-169.

BERGO, C. L. L., et al. Estimation of genetic parameters and selection of Coffea canephora progenies evaluated in Brazilian Western Amazon. Coffee Science, v.15, 2020. Available from: $<$ https://doi.org/10.25186/.v15i.1663>. Accessed: Oct. 22, 2020. doi: $10.25186 / . v 15 i .1663$.

CIRIELLO, V., et al. Doses of nitrogen on initial growth and nutrition of guanandi plants. Cerne, v.20, n.4, p.653-660, 2014 Available from: <https://doi.org/10.1590/01047760201420041445 >. Accessed: Oct. 22, 2020. doi: 10.1590/01047760201420041445.

COLODETTI, T. V., et al. Nitrogen availability modulating the growth of improved genotypes of Coffea canephora. African Journal of Agricultural Research, v.10, n.32, p.3150-3156, 2015. Available from: <https://doi.org/10.5897/AJAR2015.9692>. Accessed: Oct. 22, 2020. doi: 10.5897/AJAR2015.9692.

COVRE, A. M., et al. Vegetative growth of Conilon coffee plants under two water conditions in the Atlantic region of Bahia State, Brazil. Acta Scientiarum. Agronomy (Online), v.38, p.535, 2016. Available from: <https://doi.org/10.9755/ejfa.2016-04-341> Accessed: Oct. 22, 2020. doi: 10.4025/actasciagron.v38i4.30627.

CUNHA, A. C. M. M., et al. Role of mineral nutrition in the formation of adventitious roots in woody plants. Pesquisa Florestal Brasileira, n.58, p.35, 2009. Available from: <https:// doi.org/10.1590/S0100-06832009000300012>. Accessed: Oct. 22, 2020. doi: 10.1590/S0100-06832009000300012.

CRUZ, J. L., et al. Níveis de nitrogen e a taxa fotossintética do mamoeiro "Golden". Ciência Rural, v.37, n.1, p.64-71, 2007. Available from: $<$ https://www.scielo.br/scielo.php?script=sci artt ext\&pid=S0103-84782007000100011> Accessed: Apr. 02, 2021. doi: $10.1590 / \mathrm{S} 0103-84782007000100011$.

DALCOMO, J. M., et al. Growth comparison of 22 genotypes of conilon coffee after regular pruning cycle. African Journal of Agricultural Research, v.12, n.1, p.63-70, 2017. Available from: $<$ https://doi.org/10.5897/AJAR2016.11261>. Accessed: Oct. 22, 2020. doi: 10.5897/AJAR2016.11261.

DIAS, P. C., et al. Estaquia e miniestaquia de espécies florestais lenhosas do Brasil. Pesquisa Florestal Brasileira, v.32, n.72, p.453, 2012. Available from: <http://www.lerf.esalq.usp.br/ divulgacao/recomendados/artigos/oliveira2012.pdf $>$. Accessed: Oct. 22, 2020. doi: 10.4336/2012.pfb.32.72.453
DICKSON, A., et al. Quality appraisal of white spruce and white pine seedling stock in nurseries. Forest Chronicle, v.36, p.10-13, 1960. Available from: <http://dx.doi.org/10.5558/tfc36010-1>. Accessed: Oct. 22, 2020. doi: 10.5558/tfc36010-1.

DUBBERSTEIN, D., et al. Influence of fertilization on vegetative growth of coffee trees in the southwestern Amazon. Coffee Science, v.12, p.50-59, 2017. Available from: <https://doi. org/10.25186/cs.v12i2.1228>. Accessed: Oct. 22, 2020. doi: $10.25186 /$ cs.v12i2.1228.

ESPINDULA, M. C., et al. Seedling production. In: MARCOLAN, A.; ESPINDULA, M. C. Café na Amazônia. Brasília: Embrapa, 2015. Cap.6, p.129-154

ESPINDULA, M. C., et al. DIFFERENT VOLUMES OF TUBES FOR CLONAL PROPAGATION Coffea canephora FROM SEEDLINGS. Coffee Science, v.13, p.33-40, 2018. Available from: $<$ https://doi.org/10.25186/cs.v13i1.1353>. Accessed: Oct. 22, 2020. doi: $10.25186 /$ cs.v13i1.1353.

ESTEVEZ, R. L., et al. Doses of calcium sulphate increase the peroxidase activity and the rooting of eucalyptus clones. Forest Science, v.30, n.2, p.396-405, 2020. Available from: $<$ http://dx.doi. org/10.5902/1980509834369>. Accessed: Oct. 22, 2020. doi: $10.5902 / 1980509834369$.

FERRÃO, R. G., et al. Cultivars of conilon coffee. In: FERRÃO, R.G., et al. Café Conilon. Vitória: Incaper, 2007. p.203-225.

FERREIRA, P. V. Experimental statistics applied to agricultural sciences. 1.ed. Viçosa: Editora da UFV, 2018. v.1. 590p.

FERREIRA, O. G., et al. DDA: Determinador digital de Áreas Software para determinação de área foliar, índice de área foliar e área de olho de lombo - Versão 1. 2. Santo Augusto: Instituto Federal Faroupilha, 2008.

GIURIATTO JÚNIOR, J. J. T., et al. Growth and physiological quality of Robusta coffee clonal seedlings. Revista Ciência Agronômica, v.51, n.4, e20196920, 2020. Available from: $<$ https:// doi.org/10.5935/1806-6690.20200063>. Accessed: Oct. 22, 2020. doi: $10.5935 / 1806-6690.20200063$.

GONÇALVES, E. D. O., et al. Nutrition of seedlings of mimosa Caesalpiniae folia Benth. under different doses of N, P, K, Ca and Mg. Forest Science, v.23, n.2, p.273-286, 2013. Available from: $<$ http://dx.doi.org/10.5902/198050989274>. Accessed: Oct. 22, 2020. doi: 10.5902/198050989274.

GROSSNICKLE, S. C. Why seedlings survive: influence of plant attributes. New Forests, v.43, n.5-6, p.711-738, 2012. Available from: <https://doi.org/10.1007/s11056-012-9336-6>. Accessed: Apr. 02, 2021. doi: 10.1007/s11056-012-9336-6.

HARTMANN, H. T. et al. Hartmann and Kester's Plant Propagation: Principles and practices. 8th. ed. Boston: Prentice Hall, 2011, 915p.

HOLZSCHUH, M. J., et al. Nutrient uptake and growth of rice with combined ammonium and nitrate supply. Revista Brasileira de Ciência do Solo, v.35, n.4, p.1357-1366, 2011. Available from: <http://dx.doi.org/10.1590/S0100-06832011000400030>. Accessed: Oct. 22, 2020. doi: 10.1590/S0100-06832011000400030.

MAGIERO, M., et al. Vegetative growth of Conilon coffee tree fertirrigated with different parcels and doses of nitrogen and 
potassium.Agro@mbiente on-line, v.11,p.31-39, 2017. Available from: <http://dx.doi.org/10.18227/1982-8470ragro.v11i1.3336>. Accessed: Oct. 22, 2020. doi: 10.18227/1982-8470ragro. v11i1.3336

MARCOLAN, A. L., et al. Manejo nutricional. In: MARCOLAN, A. L.; ESPINDULA, M. C. Café na Amazônia. 1.ed. Brasília: EMBRAPA, 2015. Cap.8, p.185.

MONTES R. M., et al. Nitrogen and potassium fertilization in a guava orchard evaluated for five cycles: Effects on the plant and on production. Revista Brasileira de Ciência do Solo, v.40, 2016. Available from: <https://doi.org/10.1590 /18069657rbcs20140532>. Accessed: Oct. 22, 2020. doi: $10.1590 / 18069657 \mathrm{rbcs} 20140532$

MORAES, M. S., et al. Characterization of gametophytic selfincompatibility of superior clones of Coffea canephora. Genetics and Molecular Research, v.17, p.1-10, 2018. Available from: $<$ https://www.geneticsmr.com/articles/18018>. Accessed: Oct. 22, 2020. doi: $10.4238 /$ gmr16039876.

OLIVEIRA, A. F., et al. Desempenho de jardins clonais de oliveira obtidos por estaquia e enxertia em corte sucessivos. Scientia Agraria, v.11, n.4, p.299-305, 2010. Available from: <http:// dx.doi.org/10.1016/S0022-474X(00)00016-3>. Accessed: Oct. 22, 2020. doi: 10.5380/rsa.v11i4.18264.

OLIVEIRA, T. P. D. F. D., et al. Nutritional requirement and productivity in clonal minijardim of Toona ciliata var. australis. Forest Science, v.29, n.3, p.1154-1167, 2019. Available from: $<$ https://doi.org/10.5902/1980509821276>. Accessed: Oct. 22, 2020. doi: $10.5902 / 1980509821276$.

OOSTERHUIS, D. M., et al. The physiology of potassium in crop production. Advances in Agronomy, v.126, p.203-233, 2014. Available from: $<$ https://doi.org/10.1016/B978-0-12-8001325.00003-1>. Accessed: Oct. 22, 2020. doi: 10.1016/B978-0-12$800132-5.00003-1$

PARTELLI, F. L. et al. Estimativa da área foliar do cafeeiro conilon a partir do comprimento da folha. Revista Ceres, v.53, n.306, p.204210, 2006. Available from: <http://www.ceres.ufv.br/ojs/index.php/ ceres/article/view/3131/1026>. Accessed: Apr. 02, 2021.

PEIXOTO, C. P., et al. Quantitative analysis of growth by plants: Concepts and Practice. Enciclopédia Biosfera, v.7, n.13, p.51-76, 2011. Available from: <http://www.conhecer.org.br/ enciclop/2011b/ciencias \%20agrarias/analise \%20quantitativa. pdf $>$. Accessed: Oct. 22, 2020

PETRY, H. B., et al. Propagacao de avocadoiro via estioladas estacas. Bragantia, v.71, n.1, p.15-20, 2012. Available from: $<$ https://www.scielo.br/j/brag/a/Mjzk4gtSynjDhzFpqx869NM/?fo rmat $=$ pdf\&lang $=$ pt $>$. Accessed: Oct. 22, 2020. doi: 10.1016/B9780-12-800132-5.00003-1.

PICOLOTTO, L., et al. Rooting of blackberry cuttings as a function of nitrogen fertilization in the parent plant. Revista Ceres, v.62, n.3, p.294-300, 2015. Available from: <http://dx.doi.
org/10.1590/0034-737X201562030009>. Accessed: Oct. 22, 2020. doi: $10.1590 / 0034-737 X 201562030009$.

RAMALHO, A. R., et al. Genetic progress of processed coffee productivity with the selection of 'Conilon' coffee clones. Revista Ciência Agronômica, v.47, n.3, p.516 - 523, 2016. Available from: $<$ http://dx.doi.org/10.5935/1806-6690.20160062>. Accessed: Oct. 22, 2020. doi: 10.5935/1806-6690.20160062.

ROCHA, J. G. D., et al. Nitrogen uptake kinetics and accumulation of soluble nitrogen fractions and sugars in sunflower. Tropical Agricultural Research, v.44, n.4, p.381-390, 2014. Available from: $\quad<$ http://dx.doi.org/10.1590/S1983-0632014000400009>. Accessed: Oct. 22, 2020. doi: 10.1590/S1983-0632014000400009.

ROCHA, R. B., et al. Melhoramento genético de Coffea canephora: Considerações e metodologias. In: MARCOLAN, A.; ESPINDULA, M. C. Café na Amazônia. Brasília: Embrapa, 2015, Cap.5, p.101-122.

SILVA, F. C. Manual de análises químicas de solos, plantas e fertilizantes. Brasília: Embrapa Informação Tecnológica, 2009. 627p.

SANTOS, H. G. et al. Sistema Brasileiro de Classificação de Solos. 3.ed. Brasília: Embrapa, 2018. 356p.

SANTOS, M. R. A., et al. Propagacao vegetativa in vitro de híbridos de Coffea canephora por meio da embriogênese somática. South American Journal of Basic Education, Technical and Technological, v.7, p.155-162, 2020. Available from: <https:// periodicos.ufac.br/index.php/SAJEBTT/article/view/2710>. Accessed: Oct. 22, 2020.

SOARES, C. B., et al. Nitrogen sources and doses on growth and quality of seedlings of Cassia grandis and Peltophorum dubium. Revista Árvore, v.41, n.2, 2017. Available from: < https://doi. org/10.1590/1806-90882017000200014>. Accessed: Oct. 22, 2020. doi: 10.1590/1806-90882017000200014.

TAIZ, L., et al. Physiology and plant development. 6th.ed. Porto Alegre: Artmed, 2017, 858p.

TEIXEIRA, A. L., et al. Performance of intraspecific hybrids (Kouillou x Robusta) of Coffea canephora Pierre. African Journal of Agricultural Research, v.12, p.2675-2680, 2017. Available from: <https://doi.org/10.5897/AJAR2017.12446>. Accessed: Oct. 22, 2020. doi: 10.5897/AJAR2017.12446.

VERDIN FILHO, A. C., et al. Growth and quality of clonal plantlets of Conilon coffee (Coffea canephora Pierre ex A. Froehner) influenced by types of cuttings. American Journal of Plant Sciences, v.5, p.2148-2153, 2014. Available from: <http:// dx.doi.org/10.4236/ajps.2014.514227>. Accessed: Oct. 22, 2020. doi: 10.4236/ajps.2014.514227.

VERDIN FILHO, A. C., et al. Quality of clonal plantlets of Coffea canephora Pierre ex A. Froehner produced using coffee husk in the substrate. African Journal of Agricultural Research, v.13, p.2826-2835, 2018. Available from: <https://doi.org/10.5897/AJAR2018.13592>. Accessed: Oct. 22, 2020. doi: 10.5897/AJAR2018.13592. 